\title{
The Military Forces as an instrument of the socialization of the State
}

\section{Fabián Ricardo Giraldo-Chaparro}

https://orcid.org/0000-0002-3855-5648

fabian.giraldo@buzonejercito.mil.co

Escuela de Armas Combinadas del Ejército (ESACE), Bogotá D.C., Colombia

How to cite: Giraldo-Chaparro, F. (2019). The Military Forces as an instrument of the socialization of the State. Revista Cientifica General José María Córdova, 17(28), 939-970. http://dx.doi.org/10.21830/19006586.517

Published online: October 1, 2019

The articles published by Revista Cientifica General José Maria Córdova are Open Access under a Creative Commons license: Attribution - Non Commercial - No Derivatives.

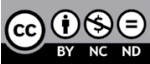

Submit your article to this journal:

https://www.revistacientificaesmic.com/index.php/esmic/about/submissions
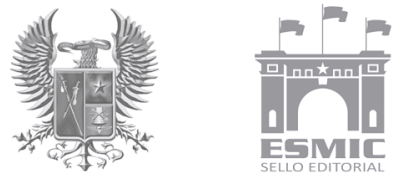

\section{Miles Doctus}




\section{The Military Forces as an instrument of the socialization of the State}

\section{Las Fuerzas Militares como instrumento de socialización del Estado}

\section{Fabián Ricardo Giraldo-Chaparro}

Escuela de Armas Combinadas del Ejercito (ESACE), Bogotá D.C., Colombia

ABSTRACT. Most states continue building their Armed Forces with the premise of providing security for their citizens. This current process has motivated discussions from favorable and opposing positions. It has become a source of considerable disagreement between political parties, ethnic and religious groups, and even among generations. Because the Armed Forces are associated mainly with the use of force to obtain peace, the training of future military officers in the use of lethal means creates a contradiction in the eyes of many societies. This article demonstrates that the Armed Forces can be seen as a contributor to the socialization of any society. Moreover, they can be perceived as a source of moral strength and the foundation for the development of a nation on different levels.

Kerwords: Napoleonic Army; Prussian Army; Roman Empire; socialization; the United States Armed Forces

RESUMEN. La mayoría de los Estados continúan construyendo sus Fuerzas Armadas bajo la premisa de brindar seguridad a sus ciudadanos. Este proceso ha motivado discusiones tanto a favor como en contra, lo cual ha generado una serie considerable de desacuerdos entre partidos políticos, grupos étnicos y religiosos e, incluso, entre generaciones. Las Fuerzas Armadas están asociadas principalmente con el uso de la fuerza para obtener la paz, no obstante, el entrenamiento de futuros oficiales militares en el conocimiento y operación de medios letales crea una contradicción a los ojos de muchas sociedades. Este artículo intenta demostrar que, contrario a la imagen errada que ciertos sectores puedan tener, las Fuerzas Armadas contribuyen positivamente a la socialización del Estado. Además, pueden ser percibidas como una fuente de fortaleza moral y como base para el desarrollo de una nación en diferentes niveles.

Palabras Clave: Ejército napoleónico; Ejército prusiano; Fuerzas Armadas de los Estados Unidos; Imperio romano; socialización

Section: DossIER $\bullet$ Scientific and technological research article

Received: June 30, 2019 • Accepted: September 2, 2019

CoNTACT: Fabián Ricardo Giraldo-Chaparro 凶 fabian.giraldo@buzonejercito.mil.co 


\section{Introduction}

Through history, the Armed Forces have been one of the permanent and, arguably, most important actors to shape the current world order. Although they were not always referred to as Armed Forces, it is easy to correlate their function, for instance, with armies or navies, especially, in the ancient times. Beyond this role, the Armed Forces (AF) act in matters of defense. Looking at the broader history of humankind to analyze what, and in what way, the Armed Forces have contributed to the socialization of society is thought-provoking.

Discussions in the Federalist Papers between liberals and republicans about the socialization of citizens through military or any other kind of public service urge the review of the potential implications of the use of public service and to what extent it should be employed in this endeavor (Burk, 2002, pp. 7-29). This article supports the idea of using armed forces as an instrument of socialization of society, under regular percentage or current size of the military organization. Its aim is not to develop this capacity further; instead, it provides an additional justification for the investment in the domestic or foreign armed forces, from the perspective of contribution to prosperity.

The literature describes socialization as a transformation process undergone by civilians when becoming a member of the Armed Forces (Cooper, Caddick, Godier, Cooper \& Fossey, 2018, pp. 156-177). In this process, people are exposed to new information and then incorporate this knowledge into how they perceive themselves, their world, and their place within that world (Atkinson, 2014, p. 19). Alastair Johnston's -a renowned social scientist, specializing in the theory of socialization-defines socialization as a process by which social interaction leads novices to embrace expected ways of thinking, feeling, and acting (Atkinson, 2014, p. 20). In the armed forces, during basic training, recruits undergo a forced separation from civilian life and emerge with a strong identification with the military organization and culture. This culture is grounded in a strict code of discipline to which recruits must quickly become accustomed. As Godfrey, Lilley, and Brewis (2012) state, the deliberate organizational socialization that takes place within basic training is aimed at producing disciplined bodies capable of carrying out military labor and waging war on the enemy. The civilian is thus incorporated into the military organization and inscribed with the specific cultural values, including loyalty, integrity, courage, determination, and commitment to duty, that the military seeks to promote. The process of basic training, whereby recruits first encounter military culture and its associated values, is likened to Goffman's (1976) concept of the "total institution," in which the recruit is separated from the rest of society and is devoid of any offstage area to withdraw, ensuring that any sense of a prior identity or individuality is removed, and achieving a full integration into the organizational environment (Cooper et al., 2018). So, how has the socialization process occurred throughout history in the Armed Forces? How do some of these practices continue complementing the current shape of society? Is it possible to emphasize that the Armed Forces can be seen as a valid instrument for the socialization of society? 
War itself has provided a useful account of the debate in a collection of essays entitled Total War and Social Change and edited by one of its protagonists, Arthur Marwick. Marwick (1988), who sought to analyze the consequences of the First and Second World Wars in a series of important publications, stresses four main ways in which large-scale wars are likely to cause societal change. War, he argues, inherently involves the destruction of life, property, and old patterns of behavior; it tests a society's social, political, and economic institutions. It provides a psychologically significant experience, and it may -especially in the case of the Total War in the twentieth century- involve mass participation of the affected population. Elsewhere in the same volume, Alastair Reid expands this suggestion, arguing that the higher the population proportion involved in a war effort, the more likely social reforms were to result. He cited, in particular, the increased influence of trade unions in collective bargaining in Britain following the First World War (Reid, 1988; Rich \& Shipley, 1993, p. 93).

The central theme of Andreski's work -which can be traced back to Aristotle (e.g. Pol. 4.1289 b) - is that the social and political framework of a society is significantly linked to the military organization of that society, the size of its armed forces, how they are recruited, and how they operate. In particular, the degree of social stratification in a society is closely linked to the extent of participation in military activity within that society (Rich \& Shipley, 1993, p. 94).

Finding answers to the previous questions is possible using historical evidence from several examples. However, this article will focus on the following four major experiences: The Roman Army during the Roman Empire, the French Army under Napoleon, the Prussian Army, and the United States Armed Forces, concluding with some specific examples from other armed forces. This research aims to provide enough material to inquire whether looking at the armed forces from this angle is valid and offers it more significance than just as a mere instrument for defense.

\section{The Roman army}

Ancient Roman history continues to define how the world is understood in contemporary times; it continues to underpin Western Culture and politics (Beard, 2016, p. 15). The Roman Empire lasted for 510 years, from 31 BCE to 476 CE (Smith, 2016, p. 20). However, the political history of the Roman rule can be divided into two broad periods. The first is the Republic, which stretches from the founding of the city of Rome in 508 $\mathrm{BC}$ to the assassination of Julius Caesar on the Ides of March in $44 \mathrm{BC}$. The second is the period of the Empire, which extends from the rule of Emperor Caesar Augustus (ruled 27 BC-AD 14) until the dismissal of Rome by Alaric, a Visigoth chieftain, in AD 410 (Opello \& Rosow, 2004, p. 19). These periods were built on many notable military victories but also significant setbacks. All these actions involved both politics and the military, which were merged into a solid block of ideas and decisions at that time. 
This was a culture of stern discipline and constant drilling of the Roman soldier, as registered in Vegetius' De Re Militari (Phillips, 1985, p. 69) primed by troubles; the Spaniards surpassed the Romans not only in numbers but also in physical strength; the Africans were superior in wealth and unparalleled in matters of deception and strategy; and the Greeks, indisputably, were far superior in skill, arts, and all kinds of knowledge (Phillips, 1985, p. 75). This setting required an Empire to be aware of its military capacity. Ultimately, this entire endeavor ended bringing changes to society, as well as to the ways to exercise politics, economy, engineering, art, and so on.

The Roman Empire, which expanded greatly under Caesar Augustus (ruled 27-14 $\mathrm{BC}$ ), reached its highest territorial magnitude during the reign of Trajan (ruled 98 - AD 117). Rome's army was stationed along the Empire's frontiers and made up of peasants recruited form the countryside. It constituted the world's first standing army, that is, a permanent military force paid, fed, clothed, and armed by the city-state. Enlistments were long (twenty years), after which legionaries were given a lump-sum payment equal to thirteen years' service or a grant of land. The Roman army was the finest military organization of its time, well trained, incredibly disciplined, and extremely mobile. It was virtually invincible from the Punic Wars to the third century AD. At its strongest, the Roman army numbered about six hundred thousand men and consumed about 75 percent of the state's budget (Opello \& Rosow, 2004, p. 23). The impact of having an army of this magnitude changed the dynamics within society.

Having an army with such a high budget (75 percent of Rome's entire budget) implied the required efforts of the whole concept of society towards the massive organization. It could be claimed that the impact on the economy, culture, infrastructure, even religion, among other factors, concerned the military. It is worth noting that soldiers were a separate part of society, viewed with a mixture of respect, incomprehension, and dislike by the civilian population, as some armies were stationed in the frontier provinces, and only occasionally had major wars to fight. The rest of the Empire's subjects enjoyed the Pax Romana -the Roman peace (Rich \& Shipley, 1993, p. 6)- which was guaranteed by the armed forces.

To understand the Roman organization, it is important to mention that all Roman citizens were subject to the military service. Apart from the poorest and freedmen (who were ineligible for the legions), most, if not all, Roman citizens of the early and middle Republics served in several year campaigns during their youth (Rich \& Shipley, 1993, p. 1), indicating the level of involvement of the society in the military organization. For the Romans, valor in arms won the highest fame, and members of the elite were under heavy pressure to enhance their family's glory by distinguishing themselves in war (Rich \& Shipley, 1993). The higher the reputation, the more opportunities one had to become a well-known politician, but, achieving this status required success in arms where skills, discipline, and knowledge were essential. 
However, military service has not always been like this. The earliest Roman army consisted of the king, his retainers, the nobles, and whatever clan members could be organized to fight, mostly in raids against neighboring communities. It was a citizen militia habituated to seasonal warfare, during which soldiers were motivated by ideas of survival, self-defense, and patriotism to ensure the survival of the Roman State (Campbell, 2002, p. 22). Also worth mentioning is the ferocity of Roman troops, reflected in the alleged intimidation of a Macedonian soldier. It has been suggested that the Romans had an apparent willingness to use violence against those they perceived to be alien peoples and behaved somewhat more ferociously than most of the other politically advanced peoples of the Mediterranean world (Campbell, 2002, p. 23). This behavior offers a different perspective of the character of Roman soldiers, their attitude, and the idea of going to battle to kill those considered their enemies, a characteristic of the society of the time.

The Roman invasion in third century BC extended simultaneously eastwards against the Greeks and Macedonians and to the West and the South against Carthage, the great commercial and military power that had grown out of a Phoenician colony in present-day Tunisia. The situation generated three Punic wars $(264-241 \mathrm{BC}$, for Sicily; 218 - 201 BC, for Italy and Spain; and 149 - 146 BC, for Carthage itself). These presented a struggle for the central Mediterranean, culminating in the abject destruction of Carthage (Parker, 2005, p. 50).

The former events were followed by constant battles against Germanic tribes (the Cimbri and Ambrones, 113 -102 BC), and to the South against African Jugurtha in Numidia (112 - 106 BC), and East against Mithridates of the Black Sea region (96-82 $\mathrm{BC}$ ), which demanded either restructuring of the republican legions or the cessation of further such interventions altogether (Parker, 2005, p. 50). Faced with this situation, the dynamic of the war as a constant model through history seems to give rise to a new dilemma for the Romans, whose continuous campaign, which now spanned the entire Mediterranean and took place during the entire year, left little chance for legionaries to return home and farm after a series of summer battles (Parker, 2005, p. 50), delivering a new set of requirements for the soldiers involved, thus society.

This new condition required permanent, professional troops to master skills beyond those of mere battlefield combat to construct, craft, as well as siege and police garrison walls, forts, harbors, and entire frontiers. Given this situation, it is possible to assert that society required this new role for the military, but the foundation for this new role was still the discipline and skills acquired, mainly, from military experience and education. It is an example where the Roman Army used its military to not only expand its vast territories but also consolidate and build its society abroad.

These events caused the legions to be called on to create physical infrastructure in the provinces from virtually nothing. Of their later activity as permanent garrison troops in Egypt, an anonymous Roman historian of the fourth century $\mathrm{AD}$ observed: 
There are still to be viewed in very many parts of the Egyptian cities, public works of the emperor Probus (AD $276-82$ ), which he had constructed by military labor (...) he built bridges, temples, porticoes, and basilicas, all by the labor of the soldiers, and he dredged many river-mouths, drained a large number of marshes and converted this into good agricultural land. (Parker, 2005, p. 50).

If Roman soldiers were to take on the combined roles of professional killers, construction workers, and occupational guards, they needed a much higher degree of training and organization.

For a portion of the society, having military members from all ranks and skillsets in a level of discipline and professionalism helping in the construction of society can be seen as a luxury. For others, this can generate disapproval, perhaps due to the ignorance of all its capacity with noble causes; others yet can also see it as a waste of precious resources that should be dedicated solely for the cause of war, or the defense of sovereignty. What many do not see is that the military is part of their own community, their own family, and their own society, that beyond its initial purpose, its capacity can be employed in other matters out of necessity or simply because there is not always war. On the other hand, all the experience, the skills, and -perhaps some resources as well- can be used once the soldier is discharged from active duty.

Rome was not always at war, nor its troops always engaged in a war. These circumstances opened spaces for continuous reforms; for instance, a professional long-service army replaced the old citizen militia. The practice of raising additional troops to fight a specific war and discharging them when the war was over was ended during the Augustus era (Rich \& Shipley, 1993, p. 5). These decisions drove Augustus' dissolution of the link between citizenship and military service; this had a price. That link had assured the Republic of a vast reserve of manpower, which enabled it to surmount its greatest crises. The army of the later Roman Empire, though larger than under the princedom, proved unequal to the barbarian challenge (Rich \& Shipley, 1993, p. 7).

On other fronts, and other times, the same dynamic gave rise to the hiring of armies. For instance, Sulla, a junior officer under Marius in the war against Jugurtha, joined forces with his old mentor (and former bitter rival) in bringing to an end the so-called Social War $(90-89$ BC) against Rome's allied Italian states (the socii), which received the formal rights of Roman citizenship, with equal opportunity to join the Roman army (Parker, 2005, p. 55). Measures like this brought Rome other challenges such as the rebellions under Sertorius in Spain ( $80-72$ BC) and Salve uprisings led by Spartacus (73 - 71 BC), among others (Parker, 2005, p. 55). These events also led to new changes in society, a result of decisions about military service.

By Caracalla's edict of AD 212, nearly all the subjects of the Empire had Roman citizenship. However, the Roman state did not turn to them to offset the military deficit; instead, they employed barbarians to fight on its behalf. The Romans had always employed 
allied troops, but with rare exceptions (like the defeat of Scipio in Spain in 211 BC), they had ensured that the preponderance of allies did not become so high as to threaten their security. Later, this principle was forgotten (Rich \& Shipley, 1993, p. 7). Roman history provides, perhaps, an excellent example of what happens when there is a rift between the armed forces and society. Peace, which was achieved by a series of military actions, was taken for granted by society. When minor threats remained, Roman society opted to use barbarians, which proved to have challenging results for their society.

A possible explanation for the above behavior could be an answer to a regular cycle of societies where the relations between the armed forces and society vary according to the level of threat. If the level of threat is high, then society, under its leadership and institutions, establishes a capable military, resulting in a strong civil-military relationship. If the military succeeds, not only in protecting its population but also in being a model for them, then, there will be more chances of a long-lasting relationship. Once peace is achieved and the level of threat reduced, lack of interest in the military results in a weak and fragile relationship. Because the levels of Roman belligerence fluctuated, fundamental changes took place in the nature of their military commitments. In the second half of the second century, for instance, opportunities for war and expansion were often missed, and many consuls did not engage in warfare at all (Rich \& Shipley, 1993, p. 53), obeying to a normal cycle of conflict, which could explain the shifts in civil-military relations.

Other contributions to society could be discussed from the individual capacity of acquisition that activates the economy. When a soldier volunteered or was conscripted into the army, it was for a specific campaign rather than a specific number of years (Rich \& Shipley, 1993, p. 98). Many of the volunteers who came forward did so because they saw that those who had served in earlier campaigns in the East had become rich. Certainly, a soldier could, if he was lucky, acquire substantial amounts of booty, but the length of time he would normally be obliged to serve away from home might well mean that he would find himself competing on the open market to buy land to replace his original property (Rich \& Shipley, 1993, p. 99). This practice suggests the promotion of the economy. Although the Romans, like other ancients, lacked a systematic view of economics, either viewing it as an abstract theory or an activity independent of politics, the basic principle that institutions are involved in economics as soon as transactions reach a relevant size and cost was acceptable (Scheidel, 2012, p. 25).

During the Second Punic War, soldiers were occasionally given small plots of land on discharge following years of service abroad, veterans were likely to have been among the settlers in Latin and citizen colonies, but the distribution of land to veterans became more of a contentious issue at the very beginning of the first century BC, following the victories of Gaius Marius over Jugurtha and then the Cimbri and Teutones. It has been traditionally conceived that an increasingly severe shortage of manpower led Marius, in $107 \mathrm{BC}$, to recruit soldiers from the poorest section of the Roman population, the capite censi. As a result, the land had to be found for them upon their demobilization, because, 
unlike ordinary recruits, they had no estates to which they could return after leaving the army. Although recent studies suggest that Marius indeed recruited from the rural peasantry, that enrolment won Marius popularity because he gave rise to the designated land grants for army veterans (Rich \& Shipley, 1993, p. 102).

Concerning the exploitation of land, there is evidence that although high demand, fostered by social equality, urbanization, and trade, played the most crucial role in permitting Greco-Roman farmers to exploit the land to its fullest potential, the structure of their society also provided a powerful stimulus to agriculture in more indirect and subtle ways. Centuriation, which still marks the modern countryside of Italy, France, Tunisia, and Spain, is the most visible indication of the transformative effect of Roman culture upon the landscape (Scheidel, 2012, p. 166). Proper distribution of land and help from the government with the agricultural challenges represented a higher production of food, which undoubtedly brought prosperity to the Roman economy. Measuring the contribution of the military, with its formation, skills, discipline, principles, and values, seems difficult; however, it can be undisputably concluded that the role of the military in all these outcomes was crucial in creating the most important empire, which, to this day is remembered for its greatness.

Romans of the early Republic made little to no distinction between civilians and soldiers. It was the duty of all men of certain property value to serve in the army and return to civilian life and their farms after the end of the campaigning season. Even in the later Republic and early Empire, when the army was beginning to be distinct from the mass of civilians, the career paths of officers still consisted of a combination of military and civilian posts (Southern, 2007, p. 76). This combination had a profound effect on the lives of civilians, not only in establishing internal law and order and protection from external dangers but also in changing and boosting the economy and contributing to a gradual Romanization of the provincials (Southern, 2007, p. 77). Here, it is possible to claim that the Roman army with all its culture of discipline and skill (Phillips, 1985, p. 75), as Vegetius stated, could influence Roman society beyond its role as an institution created for conquest and defense.

Relations between the Roman military and civilians sometimes extended to soldiers erecting buildings on behalf of civilian communities. Military architects were sometimes seconded to civilian projects. Tacitus relates, for instance, how the governor of Britain, his father-in-law Julius Agricola, encouraged and helped the Britons to build temples, marketplaces, and private houses, implying that official sanction for these activities involved the loan of military builders. Another inscription from the province of Dacia (modern Romania) records that soldiers built the walls of the city of Romula (Southern, 2007, p. 78). There is evidence of a vast contribution by the Roman army to the infrastructure of the nation, bringing innovation and solution to boost the service sector. The inspiration probably lies in the necessity of providing mobility and counter-mobility in sectors with 
limited access for tactical purposes. In the end, all this knowledge was successfully applied in sectors such as infrastructure building.

Conversely, soldiers who had been recruited from all over Italy, and their transferal -often after many years of service- to a completely different part of the peninsula, had a significant cultural impact; for example, in transforming local practices of burial and commemoration and encouraging the proliferation of more standardized tomb-monuments such as those, documented by Torelli, with Doric friezes in many areas of central and southern Italy (Rich \& Shipley, 1993, p. 108). Another ceremonial contribution from the Roman Army culture that remained in people's minds was the ever-lasting monuments that helped refine mourning practices and gave space to a new identity.

In another scenario, the old fort sites and fortresses left behind by the army after moving on to other provinces as the conquest progressed were often given to civilians where they enjoyed extended independent civilian lives. Others retained their military associations or became veteran colonies. As the frontiers were crystallized and forts became permanent, the army units settled and the relationship with civilians developed and increased. While the Empire was expanding, the primary purpose of the army was fighting battles, but once the Empire ceased to expand, the army only occasionally fought in a pre-emptive or reactionary fashion. Whenever the army settled, civilians would become an integral part of its daily transactions. Soldiers began to form relationships with local women, trade with local people, and cultivate the land. Literary and archaeological sources confirm that fields and meadows were laid out in the immediate vicinity of Roman forts. Roman occupation was not simply a matter of placing forts in isolated territories. Civilians soon moved in to take advantage of the pay that soldiers received and wanted to spend (Southern, 2007, p. 78). It is attested that in several provinces, centurions exercised judicial functions in both military and civilian cases. In some instances, because the centurion was the highest-ranking official in the vicinity or because he was the officer sent to arrest people who had been accused of crimes, his judgment was accepted by the civilians (Southern, 2007, p. 82).

Although, as stated at the beginning of this paper, the main reason for the creation of the Roman Army was the defense from different threats, its contributions to society were palpable in many fields. Over the years, the Romans built perhaps the most powerful army of the time. With this power, they set out on other endeavors, such as conquering new territories. The creation of an Army of this magnitude required enormous manpower, but more importantly, it required a doctrine, a discipline, and a set of principles and values. Sometimes with almost no distinction between civilians and members of the military, a common cultural ground made its own path in the minds of the Romans, changing the way they perceived things and bringing progress and power.

However, the actions of the Roman army were not always glorious. On some occasions, they abused their power. Some of these events are recorded, and perhaps many stories of small-scale successes have been overshadowed by those actions. What can be 
concluded is that the influence of the military in the Roman Empire was decisive, and a motivating factor for further study from the perspective of its contribution to the socialization of society.

\section{The French army}

"The Revolution changed everything and forever, though not in the way its proponents intended; the heritage was far more complex" (Fenby, 2015, p. 1). These are the words with which Jonathan Fenby, a British writer, journalist, and analyst, started one of his books about France (The Guardian, n.d.). Words that set the preamble for the complexity of the armed forces' contributions to French society during the Revolution, the imperial rule of Napoleon Bonaparte, the restoration of the Bourbon monarchy, and the period of Napoleon the III, as well as the subsequent ramifications for France.

The period of the Revolutionary and Napoleonic Wars has been called the first total war, a war that affected millions of people's lives, brought a whole continent into contact with armies and bloodshed, and subsumed the economies of most European states to the needs and exigencies of the military (Forrest, Hagemann \& Rendall, 2009, p. 1). Because it was a time of empires and kingdoms, the Napoleonic wars had implications in different regions of the world. These wars were, in many respects, part of what may be regarded as the first world war. They were also the first wars fought by all combatant parties as national wars, with mass armies recruited on the basis of universal mobilization and supplied by requisitioning and plundering (Forrest et al., 2009, p. 1), suggesting implications for the nations involved. For this study, the implications will be concerning the French population and its inhabitants.

The size of the standing army in France varied little between the end of the seventeenth century and 1789. Recent military histories have made use of the personnel records, or contrôles, of the French army of the eighteenth century, which list the details of a soldier's date of birth, birthplace, profession, and date of enrollment. From a peacetime number of about 150.000 , the army's manpower increased to a peak of approximately 400.000 in times of war, at least on paper. By 1789, there were 172 regiments, including 32 foreign ones, namely, Swiss; German; Irish; Liègois, from the Prince-Bishopric of Liège; and Hussar, theoretically Hungarian. Foreign troops were scattered throughout the army and made up about 15 percent of the total force, while French soldiers populated the foreign regiments to an ever-greater extent. Infantry regiments absorbed the bulk of the troops with over 100.000 men. Apart from the Royal household units of the French and Swiss Guards, there were also cavalry and artillery regiments (Mainz, 2016, p. 38). The size of the French Army suggests a request of an impressive amount of manpower, impacting the living culture of the French.

In this sense, the portrayal of French youth leaving the comforts and affective pleasures of civilian life, of hearth, home, family, and loved ones, to take up arms, and adopt a 
more uniform and anonymous outward appearance in the drill formations is compelling, finalizing these scenes of transition and departure with depictions of the march off to join the regiment and -in times of war-combat (Mainz, 2016, p. 31). These scenes represent not only the involvement of the society's youth in the business of war but also a change in the way of thinking, expression, and perhaps new values that conflicted with the notion of Napoleon as the highest inspiration. Comparing timespans, one can assume that these two empire's motivations were different. For the Romans, it was about Rome and its almighty connotation for future generations, expressed in its conquest of new land for the wealth of the Empire. In contrast, the French seemed to obey more to an inspirational leader who was supposed to bring progress and fundamental changes to society. Maybe both empires were looking for the same objectives, but the motivators sharply differed.

The military's influence on society can be outlined when comparing the Romans and French. While the military in the Roman era was creating a union based on its discipline and professionalism, the French military was a subject of continuous debate and, perhaps, division within the nation. There is evidence that on the eve of the revolution, the French army concealed a number of serious internal flaws behind an imposing façade. The officer corps, for instance, was divided between aristocrats who monopolized higher commands and the lesser nobles who did most of the work, but found promotions blocked for advancement (Rothenberg, 1989, p. 986). Military education was complicated by social tensions and resentment of aristocratic dominance. The king decreed the entrance to all military schools, limiting access to those who could prove that they had been born into a family that had been ennobled for at least four generations. While this regulation was not always strictly adhered to, and a number of non-noble officers were admitted over the years, the issue was very much in view when the French system of military schools was recognized and conceived during the French Revolution and Empire (Kennedy, Kennedy, Neilson, 2002, p. 5). As a result of this situation, collectively, the corps fell out of touch with rank and file. Senior non-commissioned officers, recently deprived of any hope of rising into the officer caste, were disaffected, while the ranks, overwhelmingly native volunteers with urban artisan backgrounds, tended to identify with the grievances of the third state. Thus, the cohesion of the army was fragile, and its loyalty to the crown uncertain (Rothenberg, 1989, p. 986). Indiscipline and insubordination were common in the early periods of the revolution; this condition led to the creation of Le Grand Armée.

Le Grand Armée was a product of the levee en masse (Gat, 2013, p. 246) ${ }^{1}$ of 1793 when the First Republic adopted universal service liability in order to withstand invasion by a coalition including most of the other European powers (Sondhaus, 2010, p. 21). Massive conscription-based armies raised by Napoleonic France forced all European states

1 The term "mass" connotes popular concentration, interaction, and mobilization rather than numbers because multitudes of peasants had always existed in pre-modern large states, typically comprising 85-95 percent of the population. 
to consider how to increase their military manpower, with Britain being no exception (Forrest, Hagemann, Rendall, 2009, p. 205). One of the ramifications of this practice of universalizing the military service was to be used as a driver for national socialization and the promotion of national ethos (Gat, 2013, p. 247). Arguably, as discussed previously, the military was used as an instrument to deliver a message of national identity, and beyond that, to convince the citizens of a state to accept a cause in search of mutual benefit. Undoubtedly, the military organization is a potent tool to gain adepts hopefully in the noble cause of enhancing the quality of life. However, there is a significant risk since populism in its extreme manifestation can seek other objectives, perhaps not the common ones but individual or minority objective. In this sense, the French left favored a conscript army because they viewed a professional army as a threat to liberty (Sondhaus, 2010, p. 21). This specific issue will be discussed further in this article.

Napoleon made the continent a clear strategic priority, selling Louisiana to the United States and letting rebellious Haiti go free (Sondhaus, 2010, p. 20), as mentioned previously, achieving this strategy required impressive manpower. Through the imposition of conscription, the Grande Armée saw nearly 2.5 million men pass through its ranks, 1.660.000 of whom were French. The Grande Armée constituted a social space in which a minority of professional soldiers mingled with civilians who had not chosen the profession of arms but now found themselves confronted with a war of unprecedented brutality. The challenge of the army life affected large numbers of young men who had been born into the popular classes of society. For the vast majority of them, peasant boys, in the main, and more familiar with the rigors of farm-work, exposure to the army brought a need to change their most basic assumptions and adapt to new practices (Forrest et al., 2009 , p. 45). A society should be aware of the impact of creating or enhancing a military force where scarce military culture is present. Abruptly changing the lives, especially, of young generations leads to consequences in the medium and long term for the construction or reconstruction of society. Arguably, a moderate military culture will reduce this impact. France's young generations had no other option; the new project required them, and society would face the consequences of this decision in the future.

The army was provided with only limited rations, e.g., bread. Meat was provided only during military campaigns. An individual soldier's pay had to provide them with the most basic necessities, to buy food and maintain their clothes and boots. To make matters worse, their pay was often late; soldiers risked long periods of penury and near starvation. At the end of 1806, for instance, payments were overdue by as much as five months. Soldiers' memoirs are full of complaints about their financial condition (Forrest et al., 2009, p. 45). With this outlook, a large portion of the Grande Armée had little or no resources; their logistics no longer based on army provisions, the armies now survived on general requisitioning. The armies took what they needed from the lands they marched through or fought for (Forrest et al., 2009, p. 5). Armies like the Grande Armée greatly affected the civilian population, some dying during the bombardment of villages and 
towns, others from starvation in besieged cities, and most often victims of the epidemics (especially dysentery and typhus), which soldiers brought to thousands of cities, villages, and homes all over Europe.

Being part of an army with such limitations required a special kind of motivation and leadership and that was embodied in Napoleon; the leader one had to follow to secure victory. In this sense, the men who served in the imperial armies fought less for their nation and more for one man; they must be understood in a specific context, against the backdrop of a specific war (Forrest et al., 2009, p. 48). With this context in mind, the French population's acceptance of the military forces was threatened, creating an undesired path in the minds of many citizens.

After 1815, Napoleonic veterans constituted a significant element in the political life of the early nineteenth century. Small numbers of them came to acquire significant prestige when compared with their fellow citizens in urban districts and country towns. For them, the life of the nation could be assured if France was governed by a charismatic sovereign (Forrest et al., 2009, p. 48), suggesting an important link of influence between them and the government. The fact that the White Terror (General History, n.d.) ${ }^{2}$ was also directed against soldiers reveals how the army, at the beginning of the Restoration, was far from being perceived as an incarnation of a nation mobilized against a foreign enemy. This army was, on the contrary, regarded with suspicion -a force recruited and paid by an internal enemy. For a significant part of the population in 1815, being a soldier also meant being a Bonapartist. Because of the widespread confusion that accompanied the dispersal of the army, veterans were often regarded as deserters. The new regime did little to help them normalize their administrative position. And, although the government was troubled by some of the atrocities that took place, the general air of confusion was exploited, and suspicions of the veterans persisted (Forrest et al., 2009, p. 49).

In addition to a divided army, the conditions for veterans were not the best. Legally, retirement pay was granted automatically to all of those who had completed 30 years of service. However, even if the years of campaigning counted double, this arrangement overlooked the majority of soldiers enlisted after 1804, unless they suffered from injuries causing the loss of sight or limb. Those who did would have the automatic right to retirement pay, but this was fixed at a derisory sum. After 30 years of service, the ordinary soldier received 150 francs per years, or 300 francs if he had completed 50 years of actual service; a sum that was not equal to the salary of a day laborer. As for those soldiers who were deemed incapable of achieving 30 years of service due to disabilities, they could "be nominated for

2 The so-called White Terror was an attack launched against the terrorists and all who had properly been accused of doing well from the French Revolution. White was a Bourbon color, and some historians have taken this as indicating the movement for revenge as a royalist adventure, but this is not strictly true. Very few wanted a restoration of the old régime; they simply wanted to settle old scores. Clever men had taken advantage of the Terror, grabbing land and property by force and murder, including Church lands. Many had appointed themselves as government officials, with powers emanating from the awful force of the Terror. 
retirement pay, or a simple bonus"; the King reserved the right to determine the quota of those able to benefit from this compensation (Forrest et al., 2009, p. 50).

This inevitably created serious discrimination, and those veterans who were hostile to the regime could expect little help (Forrest et al., 2009, p. 51). Evidence of this discrimination was flagrant with the Egyptians, who like other French men serving in the army, had retired after a few years of military service. These men were sent to the Depot of Egyptian Refugees in Marseille, or the smaller Depot in Paris, where they were added to the lists of those receiving pensions. Thus, Marseille, in particular, received a steady stream of young ex-soldiers, used to fighting and plundering, and with a cause for discontent. Like many soldiers, however, they still identified the Emperor as their savior against the machinations of the bureaucracy, local government, or their own community. After attempting to cut pensions expenditures by the First Restoration government, it is not difficult to imagine the jubilation of these people at the news of the Emperor's unexpected return (Bessel, Guyatt, Rendall, 2010, p. 72). In fact, it was not until the $5^{\text {th }}$ of May of 1869 that a law was passed, establishing a pension that was available to all of the former non-commissioned officers and soldiers of the Republic and Empire, though, once again, on certain conditions (Forrest et al., 2009, p. 49).

Arguably, the French Army of the $18^{\text {th }}$ and $19^{\text {th }}$ centuries might appear to have provided only a limited contribution to the socialization of society. However, this does not mean that its role was not essential for achieving the revolution's political ends. In fact, Napoleon's success was predetermined by the superiority, or at least, the greater efficiency and modernity of the French political system -in comparison to its adversaries' (Rothenberg, 1989, p. 982). Here, an important argument emerges concerning the justification of the armed forces' work with the state solely for the purpose of war or defense that disregards that the intensity and number of conflicts can decline and that such institutions require adequate regulations whose provisions go beyond mere fighting during the war. These regulations cover a myriad of fields; the most important is to provide enough conditions for the re-incorporation of the soldiers into society, assuring an added velour in the prosperity and stability of the nation.

Apart from the lack of adequate regulations for veterans, it is worth highlighting other relevant issues in the French Army. Care should be exercised when using military forces as an instrument against its people. A clear example was mentioned with the White Terror when there was a perception that the employment of the force was against State's own people. Today, there are classic examples of the use of the military against revolutionaries, terrorists, or local guerrillas. This scenario requires an adequate use of force operation, in line with the concepts of Human Rights or International Humanitarian Law. Although such detailed regulations were not present during the French Revolution, it is worth noting how a society can become divided as a result of such actions.

Finally, it is plausible to claim that the French Army was more obedient given the need to consolidate the Napoleon objectives, which, once reinforced, had to be structured 
for the future of the French Society to avoid unnecessary stresses in places like Marseille, but most importantly, to preclude the hardships of the many soldiers that served the Empire and awaited a fair payback, proportionate to their sacrifice. However, the government preferred to pay more attention to other matters, jeopardizing the future of an institution as important as le Grand Armée.

\section{The Prussian army}

More than in any other Continental State, the history of the Army in Prussia is also that of the Constitution. Very early on, the Prussian sovereigns succeeded in ending the power of the nobility; consequently, the military organization rapidly passed from a feudal system to a standing army, and popular institutions began to dominate the Landwehr (defense of the country) (Greenwood \& Smith, 1866, pp. 548-563). The creation of the Prussian Army brought about a problem similar to that of Napoleon's French Army, especially in terms of becoming a driver of the division between the civilian population and itself. Some decided to take both sides. It is interesting to explore how society was continuously impacted by the constant political debates to create an adequate standing army that would be an impartial actor in the power struggle.

Arguably, tensions with society originated at the beginning of the Thirty Years War during which mercenaries occupied the place of national troops and acted as a scourge rather than a defense for the country. Because the government was unable to procure the necessary funds to pay them in cash, they proceeded to take what they perceived was owed to them from the people amongst whom they were stationed. This naturally led to considerable abuses (Greenwood \& Smith, 1866, pp. 548-563) and unrest, which required the immediate creation of a functional state that would be strong enough to survive the threats of the time, including its neighbors' desire for power, mainly the French.

If, as it has often been said, the Prussian army created the Prussian State, it is also true that the subsequent political development of Prussia and Germany was dependent, to a far greater extent than in any other country, upon the organization of the army, its relationship to the sovereign power, and the will of its leaders. It was the army's reorganization during the period of 1807-13 that made possible Prussia's liberation from French domination and the recovery of its position as a Great Power. It was the hope of the soldiers like Scharnhorst, Gneisenau, Grolman, and Boyen that inspired that reorganization and would ensure a comprehensive political reform to create the new army (Craig, 1964).

The need for an army for defensive purposes demanded suitable national reserves. There was a system that offered the advantage of diminishing the expenses in times of peace and assured an effective defense of the state during wartime (Jomini, 1854, p. 46). Prussia started the design of an army suitable to the harmony of society that, while being reluctant to accept it, had no other option for protecting its interests and bringing an exemplary institution that inspired many foreign armies (Bara, 2012), strategists, pol- 
iticians, and academics. The army achieved by Otto von Bismarck and Helmuth von Moltke the Elder engendered scrupulous debates that at times became restless battles of ideas, and power struggles and individual interests.

The substantial severity, which characterized the Prussian discipline, encouraged desertion. The total number of desertions between 1713 and 1740 was 30.216. The most significant sources of decrease were age and sickness, which annually led to the discharge of 20 percent of the effective force. The kingdom's physical and moral foundations were shaken when as many as 180.000 Prussians died in uniform, not to mention the civilian losses from disease and privation. The social contract of the Prussian State, namely, service and loyalty in return for stability and protection, was also shaken (Olsen \& Van Creveld, 2011, p. 37). The then King, Frederick William I, soon found that he could not hope to replace these losses by relying upon volunteers. He believed in a perpetually active army, exhaustively drilled and dressed to go to battle at any moment (Greenwood \& Smith, 1866). During his early years, the King resorted increasingly to the impressment of his subjects and abundant recruiting in neighboring states, which at times was indistinguishable from kidnapping (Craig, 1964, p. 8). This situation started, perhaps, one of the most assiduous discussions of the time, concerning universal conscription vs. a professional army; this discussion would take shape later.

Rather than an obligation by law or universal conscription, there should be a moral obligation where not only every citizen feels required to serve his country but also their parents encourage this commitment as part of a traditional set of values. As Hintze wrote, the foundation must be prepared by "fixed ideas and conceptions, inherited and cultivated, and confirmed by tradition.” (Craig, 1964, p. 10). The number of recruits accepted every year should be consonant with the budget, and the capacity of the force. However, this capacity should be ambitious because the benefits, in the long run, will be more profitable for the nation.

Remarkably, the Prussian government developed a culture of self-reflection, seeking to learn from its mistakes. The Prussians created commissions, although with strong political content to, through analysis, find solutions. This was the case when the Prussian army was thoroughly defeated in 1806 . The main contributing factors to its defeat in the field were lack of organization, training, and leadership, which were already apparent since 1763 (Craig, 1964, p. 22). These findings were the product of the Military Reorganization Commission appointed by the King. This commission was instructed to investigate the recent campaign and cashier and punish those officers whose conduct had been improper, as well as to propose changes in army organization, supply, service, regulations, selection of officers, and education and training (Craig, 1964, p. 39). It is worth mentioning that the ideas of Scharnhorst (Greenwood \& Smith, 1866) and his colleagues of the Military Reorganization Commission set out not only to correct the deficiencies that had been revealed at the Battle of Jena but also, in Scharnhorst's words, "to raise and inspire the spirit of the army, to bring the army and the nation into a more intimate union 
and to guide it to its characteristic and exalted destiny." (Craig, 1964, p. 41). The union factor between society and army plays an important role even today; the governments and institutions should fight against the culture of them and us, seeking the integration of all the state's institutions.

For Hermann von Boyen, who would become Prussia's war minister in 1814 and a member of the general staff in 1806, the problem during the 1790s and 1900s, was the gradual disappearance of idiosyncratic but decisive generals from the time of the Seven Years War, such as his own commanding officer, who had barely been able to read and had given briefings in his kitchen, but who had "maintained a certain independence at decisive moments, which can only be won by a profound inner education, not by social forms." (Hewitson, 2013). Boyen emphasized a broad education for the military. After Boyen's fall, the younger officers ceased to be Boyensche in their ideals and interests, and his conception of the enlightened citizen-soldier who played a full and active role in the life of the society to which he belonged disappeared. In its place, a concept of the army as a special calling grew, followed by technicians who were essentially separate from civil society. The growth of this tendency can be found in the heated debates concerning the curriculum of the Allgemeine Kriegsschule, and the obligatory cultural -although gradual retreat of Rühle von Lilienstern from his insistence that his program should include such instruction- as well as purely military subjects (Craig, 1964, p. 80).

The scope of military preparation has been widely discussed for hundreds of years. If one of the key drivers of the creation and quality improvement of the armed forces is to socialize the society - which is the main idea in this article- the citizen-soldier should have a broader preparation. In the end, after service and return to society, the citizen should be able to contribute to generating prosperity. Nonetheless, what amount of knowledge can embrace enough capacity to face the current threats that require broader concepts emphasized on the profession? Boyan defended this idea. If it were necessary to establish a precise date of the origin of the military profession, August $6^{\text {th }}, 1808$, would be a good choice. On that day, the Prussian government issued the decree on the appointment of officers, which set forth the basic standard of professionalism with uncompromising clarity:

The only title to an officer's commission shall be, in time of peace, education and professional knowledge; in time of war, distinguished valor and perception. From the entire nation, therefore, all individuals who possess these qualities are eligible for the highest military posts. All previously existing class preference in the military establishment was abolished, and every man, regardless of his origins, had equal rights and duties (Huntington, 1985, p. 31).

In the years between 1819 and 1840, everything that Scharnhorst and his disciples had done to reconcile the military establishment with civilian society had been destroyed; the army was once more widely regarded as the main barrier to social progress. It was clear that, in the event of significant domestic upheaval, its existence would be in jeop- 
ardy (Craig, 1964, p. 81). This statement validates the long-term challenges for Prussia as a divided society, especially with the military. In any country, the implementation of armed forces should overcome all the difficulties that enhance the arguments of divisions. Neutrality perhaps is one of the most important principles that along with professionalism, can help overcome any source of division.

The first Prussian National Assembly convened on the 22 $2^{\text {nd }}$ of May, 1848 (Craig, 1964 , p. 110) to discuss military affairs. The Assembly would have been well advised to concentrate on the constitutional issues involved, to define with precision the powers of the King and the War Minister and make provision for a clear and unequivocal military oath of allegiance to the Constitution of the State. The left took the position that the time had come to abolish the regular army, which had been the source of so many of the country's ills, and to replace it by a genuine Volkswehr or popular militia, which would be the surest and only guarantee of civil freedom (Craig, 1964, p. 111). Arguably, the use of heavy weapons, preparation for attending external threats, and other military challenges require much more drill and sacrifice than those related to internal affairs. In this way, it is possible to discuss that this level of professionalism is only possible through the dedication and constant training of military personal. The ramifications, as discussed, can include citizens that are more prepared to be part of society; the military is one of the vehicles to achieve this level of skill.

Following the continuous dispute about the army in the session of 1860, a bill was laid before the lower House proposing a reorganization of the army based on the Law of 1814, about times of conscription, size of the army and funding (Greenwood \& Smith, 1866, p. 558). After several changes, the 1860 bill survived until Otto von Bismarck became president in 1862. Bismarck, of course, introduced a new bill, which, this time, required almost double the budget of the past bill-some nine million of thalers (Greenwood \& Smith, 1866, p. 558). Bismarck was fully in accord with the technical considerations that had motivated the army reform; he completely agreed that the King's power over the military command and military affairs, in general, must not be subjected to parliamentary control (Craig, 1964, p. 161), achieving thereby what the King had always insisted on. In military affairs, the Chamber had only a budgetary right; however, decisions about the size, organization, and command of the army were made by the King alone (Craig, 1964, p. 163).

In October 1862, Minister of War, Albrecht von Roon, and Bismarck, serving as Minister-President and Foreign Minister at that time, conceived an entirely new approach to the army issue related to the reform. The two ministers drafted an army service bill for submission to the Chamber that provided first, that the size of the army would henceforth be fixed at a given percentage of the population, probably 1 percent. This army would consist of two elements: long-term volunteers (Kapitulanten) comprising one-third of the total force; and conscripts that would serve for only two years. To support the volunteer formations -the existence of which presumably reduced the number of conscripts called 
annually-all eligible males were placed in the Ersatzreserve instead of being called to active duty. All conscripts wishing to ensure that their term of service would not exceed two years would pay a special tax (Einstandsgeld). Finally, instead of having to study the intricate details of a military budget, the Chamber would automatically grant a fixed annual sum (Pauschquantum) for each soldier in the army (Craig, 1964, p. 162). The funding of any endeavor will always complicate the associated decisions; this was the case in Prussia. Ultimately, the government managed to reorganize the army as necessary, but it was not easy to go on without fighting for resources. Although those were times of war, threats, battles for supremacy, and other invitations to violence, in present times, the battle for the funding of the armed force is still intense, requiring a proper and detailed justification. A professional force capable of maintaining equilibrium in society can help achieve those funds much easily.

Arguably, Minister Roon managed to overcome the impasse created by 45 years of reliance on an outdated military system and made the Prussian army fit for the Wars of Unification (1864-71), which created a new German empire dominated by Prussia (Walter, 2009, p. 270). At the very least, it can be said that Roon found a way to fund the new army, increasing its size. The German Wars of Unification transformed the political and military map of Europe. For two centuries, since the days of Louis XIV, France had been, with some exceptions, the dominant power of the European Continent. Now, this position was taken by the new German Empire. Prussia accomplished this in a remarkable feat of military proficiency, and now the world looked up to Prussia when it came to military affairs (Gat, 2001, p. 314). Becoming a benchmark for other armies required great thinkers, such as Helmuth von Moltke (the Elder) who wanted to build on the Prussian officer corps' culture of independent thinking to create an effective system of command, one which also ensured cohesion (Bungay, 2011, p. 58). Similar ideas added to the use of the staff, discipline, and effectiveness; they created a doctrine that is still present in many militaries the world, opening a new opportunity in terms of international cooperation that benefits a state because it adds prestige and international recognition, benefitting society as a whole.

The consolidation of the Prussian Army after the Thirty Years War shows a remarkable political effort through a bloody path. There are a couple of questions that should be taken into account during the reorganization of an army or armed forces more broadly. The first question is: Is the establishment of powers set? The second is, is there an adequate system of checks and balances to create an equilibrium that permits its normal functioning? Prussia was exposed to vicious debates, which sometimes seemed hopeless. However, in the end, Prussia managed to overcome all those difficulties, creating a world-class army.

Beyond all the victories, perhaps today's German culture largely reflects what brave soldiers and brilliant military and political minds offered to enhance its military culture. The great Scharnhorst, Gneisenau, Grolmann, and the Prussian Military Commission mark the beginning of the military profession in the West. They established the insti- 
tutions and ideals that dominated the Prussian forces for the rest of the century and furnished the model upon which virtually all other officer corps were ultimately based. Each nation has made its unique contributions to the culture of western society. The distinction of originating the professional officer is earned by Prussia (Huntington, 1985, p. 31). This professionalization of the military became a standard and an essential requisite for creating militaries that drive the socialization process within their respective societies.

\section{The United States Armed Forces}

Social science research on the American military during the first four decades of the twentieth century was minimal, both because the social sciences were not particularly well developed and because the military did not have a major institutional presence in the United States during a period when the country was not at war. The size of the military surged through the mobilization of the militia and conscription when the United States was engaged in combat; it declined with demobilization during interwar periods (Nielsen \& Snider, 2009, p. 195). Prior to this, in 1855, the long tradition of the US armed forces, its roots in collecting information from other armed forces to produce continuous changes in its organization (Kretchik, 2011, p. 68), contributed to creating a powerful standing armed force. In light of its size, its analysis is worthwhile given its impact on society.

In the mid-twentieth century, scholars sporadically attempted to describe the emerging structural relationships between the armed forces and their host societies in the modern world. C. Wright Mills' book, entitled The Power Elite and Harold D. Lasswell's developmental model of "the garrison state" were among the most important. Mills saw the military elite only as one actor in a national power structure. For Lasswell, the changing role of the military was driven by changes in the technology of war that increased the importance of security concerns in national agendas. His focus, however, was also on the elite. It was not until the late 1950s, at the peak of the behavioral revolution in the social sciences, that political scientists and sociologists started concerning themselves with the military, changing their focus from individual soldiers to the corporate organization of the military and its relationship with the broader society (Nielsen \& Snider, 2009, p. 197). Arguably, this change of focus brought about a new concept related to the impact of the armed forces that stretched beyond their mere use as a defense instrument for the purpose of security.

At the end of the 1960s, the Vietnam War had become the US's Greek Tragedy, its Pyrrhic victory. Despite a long record of military victories over the enemy forces - conventional and guerrilla- American soldiers and, above all, their State lost the war and, more importantly, the peace that was expected to follow. Surviving that loss and physically and psychologically recovering from it as a nation took over 20 years. Many did not survive; others survived but never fully recovered. All in all, they overcame the tragic loss (Wilson, 2013, p. 3). Between 1960 and 1963, the president, John F. Kennedy, and civilians iden- 
tified the communist-inspired insurgency as the predominant threat to the interest of the United States. Kennedy's National Security Action Memorandum No. 124 of January 18, 1962, for instance, defines insurgency as a "major form of politico-military conflict equal in importance to conventional warfare" (Thornton, 2007, pp. 150-175).

Notwithstanding such a recognition, the army remained wedded to a doctrine suitable only for conventional warfare in Europe (Miron, 2019a, p. 471; Miron, 2019b, pp. 21-25). As an American General memorably remarked of Vietnam to an interviewer from the RAND Corporation in 1970, "I'll be damned if I permit the United States Army, its institutions, its doctrine and its traditions, to be destroyed just to win this lousy war" (Beckett, 2001, p. 24). This statement indicates the determination to maintain cultural beliefs that could be shifted with a new way of thinking for the armed forces.

The Army, Navy, and the Air Force now moved further toward becoming training and administrative organizations, while the fighting edge of the armed forces was embodied in the "unified and specified commands" of the Joint Chiefs of Staff and their superiors, the Secretary of Defense, and the President (Weigley, 1977, p. 449). ${ }^{3}$ This new organization promised a different outcome. Although this type of organization prevailed, it was not enough to ensure victory in Vietnam. Endless literature on the reasons for failing in Vietnam has been written. However, for this article, it is essential to identify those reasons that produced friction in society. For instance, the fact that Lyndon Johnson's administration, relying primarily on conscripts, ignored the lessons learned by the Roman, Chinese, British, and French empires, among others. All of them had found that pacification operations far from home were seldom popular and invariably costly and long-lasting, and were generally better left to volunteer professional soldiers rather than enthusiastic citizen-soldiers whose deployment was sure to spark social unrest back home (Boot, 2013, p. 417). This division, polarization, and decisive societal pressure effectively contributed to ending the war.

The Vietnam War prevailed as a reason for division in the United States society and at the same time as a motivation for unitedness, as President Ronald Reagan put it when formally accepting the Vietnam Veterans Memorial on behalf of the nation. Reagan referred to the "scars" suffered by those who served in Vietnam and made a reference to those who had "strong opinions on the war." Having alluded to the protest stemming from the war, Reagan went on to argue that it was time to "move on, in unity," thereby rhetorically relegating a divisive experience to the past and presenting social unity as a condition necessary for America's progress into the future (Beattie, 1998). Connecting the United States' reasons for going to war in Vietnam and the rise of a new concept of war, in this case against old doctrine and culture, as well as the use of conscripts rather than pro-

3 McNamara used the authority to create multiservice commands under the Reorganisation Act of 1958 to form analogous packages in the forces themselves, bringing all combat troops into one of the various inter-service commands. 
fessionals, the war and other matters depict a remarkable impact on the society that raises questions about the political decisions on the use of armed forces and the consequences thereof for society. As mentioned before, using examples of armies from other times and other nations, this case is not any different.

Perhaps, because of the violence seen on the televisions in homes in the United States, the Vietnam war remained for a period, "the war that dared not speak its name." Vietnam veterans became the Quiet Americans (Beattie, 1998, p. 58). Then, during Ronald Reagan's administration, the Vietnam veteran was hailed a hero and allowed, even invited, to articulate his/her experience (Beattie, 1998, p. 58). The recognition of the Vietnam veterans represented a cultural change in the society of the United States, opening new opportunities for expression, creating spaces for development, identifying specific groups to promote reconciliation, and, perhaps most importantly, a segmentation of the society which, for good or for bad, has been spotted by politicians in their government plans and, especially, during their political campaigns. The United States has a veterans-leading program, inspiring other countries to follow this practice. Its current budget, under the umbrella of the Department of Veteran Affairs, is \$183.1 billion (IISS, 2018, p. 36). The military forces underwent modifications after Vietnam. These changes continue to occur following the Gulf War, the Iraq War, and the Afghanistan War; however, these will not be discussed in detail because of space limitations.

The US military is not one force but several. The first force is commonly known as the active component, which operates full time as part of the Department of Defense $(\mathrm{DoD})$ and is governed by Title 10 (United States Code, 1956) ${ }^{4}$ of the United States Code. The second major force is the Reserves, which is broken into two distinct groups. The first group is the reserves. Each service, the US Army, the US Navy, the US Air Force, the Marine Corps, and the US Coast Guard has its own reserves that operate exclusively under federal control when training at home or deployed overseas to support the active component. The second group of reservists, the National Guard, differs considerably from the first. The National Guard consists of the Army and Air National Guard, both fall under the National Guard Bureau; a federal-level headquarter under the DoD (Campbell \& Auerswald, 2015, pp. 72-73).

The reserves have played an important role in different nations throughout history. For the United States, the Reserves were a vital contributor of manpower and technology during World War I and II. However, their use decreased during the Vietnam War (Cohen, 2015, pp. 16-21), regaining its prominence, yet again, during the Global War on Terrorism (Cohen, 2015, pp. 22-29). The use of reserves implies having a force somewhat trained in military affairs, but highly skilled in civilian affairs. These skills, adequately

4 Title 10 is an Act to revise, codify, and enact into law, title 10 of the United States Code, entitled "Armed Forces," and Title 32 of the United States Code, entitled "National Guard." Title 10 and Tile 32, United States Code. Enacting during the Second Session of the Eighty Fourth Congress of the United States of America. Washington 1956. This document has been enacted in several occasions. 
balanced with the use of active force, can produce significant results on the battlefield, but beyond that, it serves to connect active military personnel with civilians to bring prosperity not only after any conflict in which they can be involved but also on a daily basis. Not many countries can have reserves integrated into the actual military. Most of the time, this is due to the scarce allocation of resources. The use of the Reserves as extensions of the active force represents an opportunity to involve society with the military for purposes of defense closer and serves as a bridge that facilitates transitions in both ways from the civilian world to the military and, most importantly, from the military world to the civilian.

A part of the contributions from the military to society is encapsulated in the compensation offered to its members. If a member of the military receives more benefits, appropriately used, this can help bring prosperity to society. For the US, the objective of the military personnel compensation system is to attract, motivate, retain, and ultimately manage the departure of service members. The military establishes compensation policies based on the unique needs and characteristics of the organization to meet these goals. For example, the military is a hierarchical organization without lateral entry that attempts to manage the supply and demand of military personnel through manpower policies such as its retirement system. Military compensation today is a combination of multiple types of pay and benefits (Campbell \& Auerswald, 2015, p. 90), such as cash pay, which includes regular military compensation and special and incentive pay, and noncash pay, which includes in-kind and deferred benefits (Campbell \& Auerswald, 2015, p. 91). Military compensation promotes personal development. It enables commercial investments in many fields in regions in which the military is deployed and prepares military personnel for a better performance during their military career, creating an experience acquisition foundation that can be used later in the civilian world. It also promotes stability and fair treatment, especially for those who are wounded and so on. Therefore, it is essential to maintain a balance with the motivation of the patriotic duty because the lack of it will mislead the core of the armed forces.

Another interesting feature of the US armed forces - similar to the Prussian Armyconcerns the exporting of security, which ultimately offers the military opportunities to acquire new experiences, new knowledge from different cultures, and perhaps, new opportunities of trade and many other exchanges for their homeland. Militaries do more than merely fight wars. Governments around the world look to the United States to assist them with their security deficits. However, advanced aircraft, ships, and tanks are not the key to secure political objectives; it is the human skills that the United States promotes and tests in combat zones that may be critical. Success is not contingent on being warriors alone; instead, military personnel must also be builders, diplomats, and guardians (Reveron, 2016, p. 13). Having this set of skills requires a different approach to building military capacity, one which is more positioned to be employed in another set of scenarios and will contribute to creating better societies (Thornton, 2000). 
Exporting security is also an instrument to improve the well-being of other societies. The United States and other countries are aware of this situation; however, the United States is the leader in military cooperation programs. A clear example of this is the expansion of its security programs which, for instance, in terms of status of force agreements went from 40 in 2000 to 117 in 2016 . Its foreign military financing budget went from $\$ 3.6$ billion in 2000 to $\$ 5.8$ billion in 2016 , and, not less impressive, its international military education and training budget increased from $\$ 58$ million to $\$ 111$ million for the same period (Reveron, 2016, p. 44). Currently, the foreign military financing budget continues to increase and is mostly used in Afghanistan (Operation Freedom's Sentinel), Iraq, and Syria (Operation Inherent Resolve) (IISS, 2018, p. 36), alongside other international cooperation programs.

The history of the US armed forces is vast and complex, and it is one of the most significant drivers for US society. During the twentieth century, and presently, the US armed forces have been the main protagonist in the most challenging wars and conflicts with significant consequences that, apart from their international impact, had ramifications in its society. Perhaps the most remarkable was the Vietnam War, which brought the horrors of war to American television, changing the American minds forever. The debate over the Vietnam War influenced many subsequent discussions on foreign policy. Almost every military initiative since then has been debated in terms whether it would lead the US into 'another Vietnam,' e.g., sending the Marines to Lebanon; invading Grenada; deploying military advisers to El Salvador; supporting the Contras in Nicaragua; helping South American countries fight drug trafficking; and sending troops to Iraq (Wilson, Dilulio \& Bose, 2014, p. 434).

The US armed forces were the object of more exhaustive follow up after the Vietnam War, producing necessary modifications, that, beyond the mere military, produced perhaps one of the most important in terms of contribution to society, President Ronald Reagan's promotion of the Veterans Administration to a cabinet-level executive department in October 1988. The change took effect on March 15, 1989, and administrative changes occurred at all levels. President George H. W. Bush hailed the creation of the new department when he said: "there is only one place for the Veterans of America, in the Cabinet Room, at the table with the President of the United States of America." The Veterans Administration was then renamed the Department of Veterans Affairs (U.S. Department of Veterans Affairs, n.d.). It certified and improved all sort of benefits, including transitions assistance, compensation, education and training, vocational rehabilitation and employment, and home loans, among many other significant benefits (U.S. Department of Veterans Affairs, n.d.), bringing progress to society through a military system.

Through its armed forces, the US government persists in its role as an exporter of security. One of the reasons for this insistence is that this can boost its defense sec-

$5 \quad$ See Table 2.1. Expanding security programs. 
tor, bringing prosperity to the nation and providing stability to different regions of the world. An interesting example of this practice is the International Military Education and Training Program (IMET), which aims to increase understanding between the US and other nations, allowing participating countries to become more self-reliant, and increase the awareness of internationally recognized human rights issues (Reveron, 2016, p. 132). Measures such as IMET open opportunities not only to the US military but also to other foreign militaries. Having access to a new technology, new practices, and, in general, a whole new concept of ideas can contribute to the socialization of their societies, on top of the defense priorities.

\section{Special considerations}

There are lingering concerns in society about the military holding an absolute monopoly on force, and how to keep it strong enough to defend the state and subservient enough not to threaten it is the central question in civil-military relations (Hooker, 2004, p. 2). Although the military is a violent institution designed by society for protection, the dilemma is finding the balance of a military strong enough to do so but not so strong as to violate its trust and bring violence to the society it is supposed to protect. Deborah Avant has called this the balance between efficiency and accountability (Morgan, 2006, pp. 202-218). Avant suggests that armed forces should be highly ordered, disciplined, but accountable. If this can be achieved, it is possible to be less concerned and, more importantly, to adjust an organization to achieve different objectives in the education of society under the amalgamation of the principles and values of a nation, less worried about the monopoly of force and the ingredient of violence.

In terms of the politics beyond the discussion on submission of power raised by Huntington or Janowitz among other renown academics, it is important to mention other concerns. First, politics is beyond the scope of military competence, and the participation of military officers in politics undermines their professionalism, curtailing their professional competence, dividing the profession against itself, and substituting extraneous values for professional values (Hooker, 2004, p. 8). Second, the role of the retired military elite should be balanced in their thinking and aware of their responsibilities during the election processes and general government activities. Their decisions can alarm the old tradition of military non-partisanship (Hooker, 2004, p. 5), and tend to politicize the armed forces in the short and medium-term excessively (Strachan, 1997, p. 1) ${ }^{6}$. Such action is not convenient for the institution. Lastly, care should be taken at the moment of using polls of social confidence. Measurement of the military by itself can lead to a positive coaxing of the results. Prestige and popularity in society might be vital to the ability to exert political leverage, legitimizing the intervention in politics. The military should not

6 "Armies are self-evidently political institutions (...) Nothing empowers a polity more succinctly than its armed forces; no act more clearly defines its ultimate interests than a decision to fight." 
act as a guarantor of democracy or other values. That used to be the case of the Turkish military, which declared itself as a defender of secularism, following a long tradition since Atatürk times. A discussion on this specific subject requires an in-depth study. However, mentioning these caveats can make governments and military elites aware of issues that must be addressed, otherwise, rather than contribute to the socialization of society, the armed forces may achieve the opposite, its division.

Contemporary military culture is tremendously complex. It involves fragmentation and harmony, traditional and current features, and multiple overlapping spheres of influence, including professional and institutional, bureaucratic, occupational, warrior, peacekeeper-diplomat, leadership and followership, multirole, versatility, and a myriad of other cultural influences, orientations, and tools (Hajjar, 2014, pp. 118-145). An interesting reflection from Dr. Remi M. Hajjar about the theory's use of the dominant military professional variable implicitly provides cultural insights regarding the purported prominent archetypical traits of the top general officers and military leaders across different eras, ranging from combat leader in the modern era (from 1900 to 1945) to the manager or technician in the later modern era (from 1945 to 1990) to the soldier-statesman and soldier scholar in the postmodern era (from 1990 to 2001) to the soldier-warrior, soldier-manager, soldier-statesman, soldier-scholar, and soldier-constable in the hybrid era (from 2001 to present). The growing complexity of the dominant military professional's crucial traits in the postmodern era hints at the emergence of postmodern military culture (Hajjar, 2014, pp. 118-145). Hajjar's statement provides ideas of the military cadre of evolution. From this perspective, it is easier to understand what is happening with the military way of thinking, its evolution, and how this new set of skills can be used in society.

It is important to stress that the military presence in civil society is not confined to serving members of the active-duty military. It encompasses all who serve or have served, both active and reserve. For example, millions of veterans with first-hand knowledge of the military and its value system exist within the population at large. The high incidence of married service members and an increasing trend towards off-base housing mean that hundreds of thousands of military personnel and their dependents live in the civilian community. Reserve component installations and facilities and the reserve soldiers, sailors, airmen, and marines who serve there bring the military face to face with society every day in thousands of local communities across the country (Hooker, 2004, p. 3).

In regards to veterans, it is important to mention two the United States and the United Kingdom. In the UK, the most up-to-date figures from the Royal British Legion Household Survey (2014) estimate that $4.4 \%$ of the U.K. population $(2.83 \mathrm{~m})$ are veterans. A further $3.2 \%$ are dependent adults $(2.09 \mathrm{~m})$ and $1.5 \%$ are dependent children (0.99). In total, it is estimated that $9.2 \%$ of the U.K. population $(5.91 \mathrm{~m})$ is part of the veteran community (Cooper et al., 2018, p. 157) and as of 2014, it is estimated that there were about 22 million living veterans in the United States (Neill-Harris et al., 2016, pp. 585-604) without counting all the persons linked to the veterans as the 
British example. These numbers provide evidence of the remarkable sizes of community that in some way receives benefits from the government through the armed forces, but they also indicate that they are in a better and deserved position after serving their countries. Furthermore, it suggests that those individuals continue supporting their nations from different positions.

Another interesting aspect is the security gap, which is a current option for the armed forces. Peter Neuteboom and Joseph Soeters (2017) provide a stimulating case study, analyzing how the Dutch military performed during security gaps in the three (post) conflict areas of Bosnia and Herzegovina, Kosovo, and Iraq. They conclude that army units were frequently involved in interim policing and de facto operated as Hybrid organizations, without leaving the military paradigm behind. Policing is generally not seen as a primary task of the military. However, to adapt to the reality of security gaps and increase the operational effectiveness in the field of public security, the military would benefit from reflecting on their current military paradigm and on what they could learn from current policing practices (Neuteboom, Soeters, 2017, pp. 711-733). That is the case of the Colombian military forces where army units ${ }^{7}$ are dedicated to combating criminal organizations due to increasing activities where local police cannot respond to the coverage demand.

However, the armed forces should stay away from any political affiliation. But how to reconcile from one side the necessity, for instance, of improving military pay, quality of life for the militaries and their families, and make the force stronger for defense purposes, with some political parties offering solutions to these necessities, but not all of them. That reconciliation is perhaps possible with adequate attention (provide enough interest as an important group of society and an organization) to the military system, focusing on its role as a guarantor of the national defense and the key player in the contribution of the prosperity of society. This adequate attention should be addressed by all political parties, staying clear from populist practices such as those promising unjust and unachievable pay raises or benefits, but remaining aware that a strong and reliable military force can guarantee national defense and can help lead society through a much better path.

\section{Conclusion}

The Romans created the first permanent army that was paid, fed, clothed, and armed by the state, and based on skills and discipline. When Rome was not at war, the legions were called to provinces to create physical infrastructure from virtually nothing. Arguably, the Romans placed their society at risk by employing barbarians to fight on its behalf. The Romans also started a program for veterans that provided lands that would contribute to local economies. Roman soldiers also brought culture to new regions; they helped with judicial functions and

7 For instance, the Counter-Narcotics Brigade, which operates against criminal organizations connected with narco-trafficking. 
many other activities, becoming incorporated fully into society. All these actions and many others suggest an arguable concept of consciousness from the Roman authorities towards their army, concerning its use as an instrument of socialization.

During the Napoleonic Wars, mass armies were recruited based on universal mobilization, changing the ordinary lives of the youth and their way of thinking, inspired not by their Nation, but by Napoleon's ideas. Desperate measures were taken to create an enormous army whose organization was flawed because of profound differences between officers and soldiers, creating tension. A conscript army was favored because a professional army was viewed as a threat to liberty. Poor conditions for veterans and discrimination degraded the lives of former militaries, creating unrest in some areas such as Marseille that received a steady stream of young soldiers used to fight and pillage. These events suggest that during the Napoleonic Wars, there was a limited concern for the armed forces as an instrument of socialization since their creation and operation was purely focused on the business of war.

Although similar to the French Army in terms of tensions between the army and government, the Prussian Army was organized for the defense of the country (Landwehr) following the disastrous experiences during the Thirty Years War and the imminent threat of the French and other neighbors. Through several re-organizations the Prussian Army managed to become one of the strongest armies, introducing a clear concept of professionalization that made the Prussian Army an effective benchmark for armies around the world. Arguably, the most significant contribution to the socialization process was the concept of professionalism in the army. This concept still inspires other countries to train their militaries to the highest standard to make them more efficient and competitive. All these characteristics are fundamental to the socialization process.

Lastly, the US Armed Forces are currently a symbol of power and technology. In the field of socialization, perhaps, its most remarkable achievements are related to their capacity of exporting security, becoming a source of cultural, technological, and academic exchange with other fields. Similarly, their comprehensive model for veterans is noteworthy, offering thousands of soldiers, and their relatives, benefits that contribute to the economy of local communities. Moreover, these groups are homogenized in a force that remains the key player in the process of socialization.

Using the evidence of the four militaries (Romans, French during the Napoleonic Wars, the Prussian Army, and the US Armed Forces), it is possible to arrive at some conclusions. Armed forces have the primary mission of protecting a nation, throughout history, they sometimes enabled conquests and expansions; however, that is not the case today and hopefully will not be in the future. They can also provide a source for work, education in military affairs, and opportunities to expose citizens to cultural exchange. They have brought about technology and other sorts of progress. Armed forces are also an instrument of violence, but that was not the focus of this paper. Today, armed forces continue to be the central pillar for defense and an invaluable asset for security and socialization. 
The objective of this article was to provide evidence of the role of the armed forces in the socialization of society by providing examples from different countries at different times. This article also calls to delve deeper in several areas concerning the impact of the direct and indirect contribution of the armed forces to the prosperity and stability of a nation. Some future studies could include identifying the role of veterans in the economy of a country, determining how government-issued benefits change the lives of veterans, their relatives, or beneficiaries and how society aims to include its militaries (veterans and active duty) in the complex process of creating prosperity, and establishing how military knowledge and skills can be harnessed to increase a society's competitiveness and what can be done to improve this situation. There are many other questions to justify the funding of the armed forces from perspectives other than mere national defense and security; many whose discussion inevitably brings the civilian leadership into conflict with the military (Herspring, 2009, pp. 667-687). Emphasizing this approach can bring a new common ground to reconciling the differences between the government and the military for society.

Lastly, reflecting on the examples of the armed forces from around the world that were part of this study suggests that they are institutions that represent, to a certain extent, the national identity of their countries. They are the guardians of the security of the states and their citizens and, most importantly, they have the possibility to create opportunities for young generations and citizens, in general, to reinforce their values, principles, culture, and identities through a challenging experience that inspires the unity of a nation, not against other nations, but against common threats and they are also, perhaps, a source of union for world prosperity.

\section{Acknowledgments}

The author wishes to thank King's College London for the support given to this article as part of his Master's degree in International Security and Strategy.

\section{Disclaimer}

The author declares that there is no potential conflict of interest related to the article.

\section{Funding}

The author does not report sources of funding for this article.

\section{About the author}

Fabián Ricardo Giraldo-Chaparro is a Colonel in the National Army of Colombia, currently serving as Chief of Staff at the Training and Education Command (CEDOC). 
He holds an MA in International Security and Strategy (King's College London) and is a graduate of the UK Defence Academy - Royal College of Defence Studies (RCDS), and the Command and General Staff College at Fort Leavenworth, United States. During his career, he has served as Commander of the Special Operations Aviation Battalion, the 33rd Aviation Brigade, and as Chief of Acquisitions for the Colombian Army Aviation. https://orcid.org/0000-0002-3855-5648 - contact: fabian.giraldo@buzonejercito.mil.co

\section{References}

Atkinson, C. (2014). Military Soft Power: Public Diplomacy through Military Educational Exchanges. Maryland: Rowman \& Littlefield.

Beard, M. (2016). SPQR: A history of Ancient Rome. London: Profile Books.

Beattie, K. (1998). The Scar That Binds: American Culture and the Vietnam War. New York; London: NYU Press.

Beckett, I. (2001). Modern Insurgencies and Counter-insurgencies: Guerrillas and their Opponents since 1750. New York: Routledge.

Bessel, R., Guyatt, N., \& Rendall, J. (Eds.). (2010). War, Empire and Slavery, 1770-1830. London: Palgrave Macmillan.

Boot, M. (2013). Invisible Armies: An Epic History of Guerrilla Warfare from Ancient Times to the Present. New York: Liveright.

Bungay, S. (2011). The Art of Action: How Leaders Close the Gaps between Plans, Actions, and Results. London: Nicholas Brealey Publishing.

Burk, J. (2002). Theories of democratic civil-military relations. Armed Forces \& Society, 29(1), 7-29.

Campbell, B. (2002). Warfare and society in imperial Rome, C. 31 BC-AD 280. London: Routledge.

Campbell, C., \& Auerswald, D. (Eds.). (2015). Congress and Civil-Military Relations. Washington: Georgetown University Press.

Cohen, R. (2015). Demystifying the Citizen Soldier. Santa Monica: RAND Corporation.

Cooper, L., Caddick, N., Godier, L., Cooper, A., \& Fossey, M. (2018). Transition from the military into civilian life: An exploration of cultural competence. Armed Forces \& Society, 44(1), 156-177.

Craig, G. (1964). The Politics of the Prussian Army 1640-1945. Oxford: Oxford University Press.

Fenby, J. (2015). The History of Modern France: From the Revolution to the War on Terror. Croydon: Simon and Schuster.

Forrest, A., Hagemann K., \& Rendall, J. (Eds.). (2009). Soldiers, Citizens and Civilians: Experiences and Perceptions of the Revolutionary and Napoleonic Wars, 1790-1820. London: Palgrave Macmillan.

Gat, A. (2013). Nations: The long history and deep roots of political ethnicity and nationalism. Cambridge: Cambridge University Press.

Gat, A. (2001). A history of military thought: From the Enlightenment to the Cold War. Oxford: Oxford University Press.

Greenwood, F., \& Smith, G. (1866). The Prussian Army. The Cornhill Magazine, 14(83), 548-563.

Godfrey, R., Lilley, S., \& Brewis, J. (2012). Biceps, bitches and borgs: Reading Jarhead's representation of the construction of the (masculine) military body. Organization Studies, 33(4), 541-562.

Herspring, D. (2009). Civil-Military Relations in the United States and Russia: An Alternative Approach. Armed Forces \& Society, 35(4), 667-687.

Hewitson, M. (2013). Princes' Wars, Wars of the People, or Total War? Mass Armies and the Question of a Military Revolution in Germany, 1792-1815. War in History, 20(4), 452-490. 
Huntington, S. (1985). The soldier and the State: The theory and politics of civil-military relations. Harvard: Harvard University Press.

International Institute for Strategic Studies. (2015). The Military Balance. London: Routledge.

Jomini, A. H. (1854). Summary of the Art of War: Or, a New Analytical Compend of the Principal Combinations of Strategy, of Grand Tactics and of Military Policy. New York: GP Putnam's Sons.

Kennedy, G., Kennedy G. C., \& Neilson, K. (Eds.). (2002). Military education: Past, present, and future. Santa Barbara: Greenwood Publishing Group.

Kretchik, W. (2011). US Army Doctrine: US Army Doctrine. From the American Revolution to the War on Terror. Lawrence: University Press of Kansas.

Mainz, V. (2016). Days of Glory? Imaging Military Recruitment and the French Revolution. London: Palgrave Macmillan.

Miron, M. (2019a). On Irregular Wars, Insurgencies and How to Counter Them: Enemy- and Populationcentric Approaches in Comparative Perspective. Revista Cientifica General José María Córdova, 17(27), 457-480. http://dx.doi.org/10.21830/19006586.497

Miron, M. (2019b). Counterinsurgency Operations in the 21st Century: Insights from the United States Army Experiences in Iraq. Bogotá D.C.: Sello Editorial ESMIC.

Morgan, M. (2006). American empire and the American military. Armed Forces \& Society, 32(2), 202-218.

Neill-Harris, K., Resnick, S., Wilson-John, W., Miller-Stevens, K., Vandecar-Burdin, T., \& Morris, J. (2016). Assessing partnerships between the military and civilian agencies to meet transitioning service members' needs. Armed Forces \& Society, 42(3)2016): 585-604.

Nielsen, S., \& Snider, D. (Eds.). (2009). American civil-military relations: The soldier and the state in a new era. Baltimore: The John Hopkins University Press.

Olsen, J. A., \& Van Creveld, M. (Eds.). (2011). The evolution of operational art: From Napoleon to the present. Oxford: Oxford University Press.

Opello, W., \& Rosow, S. (2004). The nation-state and global order: A historical introduction to contemporary politics. Boulder: Lynne Rienner.

Parker, G. (Ed.). (2005). The Cambridge illustrated history of warfare: The triumph of the West. Cambridge: Cambridge University Press.

Phillips, T. (Ed.). (1985). Roots of strategy: The 5 greatest military classics of all time. Vol. 1. The Military institutions of the Romans/by Vegetius. Mechanicsburg: Stackpole Books.

Reveron, D. (2016). Exporting security: International engagement, security cooperation, and the changing face of the US military. Washington: Georgetown University Press.

Rich, J., \& Shipley, G. (Eds.). (1993). War and society in the Roman world. London: Routledge.

Rothenberg, G. E. (1989). Soldiers and the Revolution: The French Army, Society, and the State, 1788-99. The Historical Journal, 32(4), 981-995.

Scheidel, W. (Ed.). (2012). The Cambridge companion to the Roman economy. Cambridge: Cambridge University Press. Smith, D. (2016). The State of the Middle East Atlas. Oxford: New Internationalist.

Sondhaus, L. (2010). Strategic culture and ways of war. London: Routledge.

Southern, P. (2007). The Roman army: A social and institutional history. New York: Oxford University Press, New York.

Strachan, H. (1977). The politics of the British Army. Oxford: Clarendon Press.

Thornton, R. (2000). Cultural Barriers to Organisational Unlearning: The US Army, the 'Zero-Defects' Culture and Operations in the post-Cold War World. Small Wars \& Insurgencies, 11(3), 139-159. https://doi. org/10.1080/09592310008423292 
Thornton, R. (2007). Asymmetric Warfare: Threat and Response in the Twenty-First Century. Cambridge, UK: Polity Press.

US Army Training and Doctrine Command. (2014). Pamphlet 525-3-1 The US Army Operating Concept: Win in a Complex World. Tradoc: Fort Eustis Virginia.

Van Creveld, M., \& Keegan, J. (2005). The art of War: war and military thought. New York: Harper.

Walter, D. Roon, the Prussian Landwehr, and the Reorganization of 1859-1860. War in History, 16(3), 269297. https://doi.org/10.1177/0968344509104193

Weigley, R. (1977). The American way of war: A history of United States military strategy and policy. Bloomington: Indiana University Press.

Wilson, I. (2013). Thinking beyond war: Civil-military relations and why America fails to win the peace. New York: Palgrave Macmillan.

Wilson, J., DiIulio J., Bose, M., \& Levendusky, M. (2016). American government: Institutions and policies. Boston: Cengage Learning. 